\section{Progress in the eradication of violence against women}

Source: Pan American Health Organization. Progress in the eradication of violence against women. Washington, DC: PAHO, Program on Women, Health, and Development; 1997.

\section{BACKGROUND}

During the past two decades, violence against women has been recognized as deserving of international concern and action. Women's organizations around the world embraced gender violence as a priority issue during the United Nations Decade for Women (1975-1985), and the UN has continued to pursue the issue since 1985 through sponsorship of several meetings of experts and the work of various offices. Two recent international agreements recognized all gender-based violence as an abuse of human rights: the UN Declaration on the Elimination of Violence against Women (1993) and the Inter-American Convention on the Prevention, Punishment, and Eradication of Violence against Women (1994), negotiated through the Inter-American Commission on Women of the Organization of American States. Likewise, the UN International Conference on Population and Development (Cairo, 1994) and the Fourth World Conference on Women (Beijing, 1995) highlighted violence against women as an obstacle to gender equality and a threat of great magnitude to the social and economic development of nations.

In the Declaration of La Paz, produced by the Sixth Conference of Wives of Heads of State and of Government of the Americas (1996), Conference participants expressed a commitment to "the formulation and implementation of legal policies and norms, as well as regional educational campaigns designed to prevent and eliminate all forms of family violence." The delegates to the Seventh Conference of Wives of Heads of State and of Government of the Americas, held in Panama City, Panama, in October 1997, reaffirmed that commitment. During the Conference, the factual and conceptual bases for antiviolence activities were discussed, current initiatives in Latin America and the Caribbean were reviewed, and obstacles to success were identified.

\section{CURRENT SITUATION}

Men abusing women accounts for $92 \%$ of reported incidents of domestic violence. Male violence against women is a learned behavior, a conscious and directed practice embedded in a social system fraught with gender inequality. Men attack 
women because they feel they have the right to intimidate and control them.

Because violence against women has such deep roots, efforts to prevent incidents and assist victims can succeed only by involving many actors in the public and private sectors. The Pan American Health Organization has accordingly recognized violence against women as a priority public health issue, and, since 1994, has mobilized over US\$ 7 million for the prevention of gender abuse in the Americas. Most Latin American and Caribbean countries have undertaken both national and community-level activities. The former include promotion of legal norms and policies that strengthen the institutional capacity to respond to violence against women. The latter include creation of community networks-of local legal and health workers, police and judges, churches, women's groups, NGOs, and others-which meet regularly to plan coordinated responses to the problem. The countries are also increasing their efforts to train human resources so that women who seek help and guidance from public institutions are treated humanely. Additionally, many countries try to enlist the media in efforts to modify norms of acceptance of male superiority and violence against women, and groups are being formed to help men deal with aggression.

Specifically, Argentina, Bolivia, Chile, El Salvador, Guatemala, Honduras, and Panama have recently enacted national legislation to control domestic violence. In Chile, the number of reported incidents soared following implementation of the law, to more than 50000 in 1996. Moreover, $73 \%$ of female complainants stated that their home situation subsequently improved, and 39\% of this latter group felt that their relationships with their partners improved. Bolivia is currently conducting nationwide public discussions aimed at specifying enforcement and penalty regulations related to its 1995 law. Brazil has two laws on domestic violence pending in the legislature, as well as three bills addressing sexual harassment.

The governments of Brazil, Paraguay, Trinidad and Tobago, El Salvador, and Belize have commissioned bodies to develop national plans to eradicate domestic violence. In Brazil, the National Council on Women's Rights is spearheading initiatives for a series of integrated centers for women at risk and lobbying the federal government to support state and municipal initiatives. The Ministry of Women in Paraguay has formed an interinstitutional group which includes NGOs as well as government agencies, and is operationalizing a National Plan for Equal Opportunities for Women. In Trinidad and Tobago, the National Domestic Violence Unit has set up a hotline for victims and is in the process of fostering community initiatives including a male counseling and resource center. The Unit is also instituting periodic review of the effectiveness of the Domestic Violence Act.

Bolivia, Honduras, Nicaragua, and Peru now have organizations and self-help groups dedicated to preventing family violence and supporting battered women. Bolivia has established a network of Family Assistance Police Stations which assist prosecution of cases of violence against women. Honduras now has 12 Family Bureaus. In Nicaragua, a network of Women's Commissariats is engaged in developing an integrated model of prevention and treatment.

Costa Rica has conducted three annual campaigns "For a Life Without Violence." This government is also training staff in key institutions to address gender-based violence. Bolivia is piloting educational reforms that include incorporation of gender perspectives in school textbooks. A similar educational effort, but at the graduate professional level, has been proposed in Panama.

In Argentina, the Executive Authority approved Decree 2385/93 recognizing World for Non-Violence Against Women Day and denouncing sexual harassment in public administration. Strong advocacy has kept the issue of violence against women at the forefront of public awareness as a social and political problem since the 1980s. The Argentine Department of Community Care, through a pilot project supported by the InterAmerican Development Bank and PAHO, is attempting to develop strategic guidelines for a model of comprehensive care and prevention coordinated through appropriate institutions.

The deep imprinting of gender attitudes and behaviors over the course of millennia is the most powerful obstacle to eradicating violence against women. Structural impediments also exist. In some countries, women must obtain certificates from a medical examiner or forensic physician before they can gain access to the courts, as reports issued by other health professionals are not considered legally valid. Such stipulations are counterproductive because women may find it too difficult to reach, talk to, and pay these officials.

Nevertheless, some outstanding successes can be reported. In one municipality, a deputy prefect was well known to batter his wife. For a long time, the community turned a blind eye, considering him just one batterer among many. Recently, however, a group succeeded in opening a communal dialogue about gender, violence, and human rights. The community's tolerance for domestic violence plummeted. They soon concluded that it was inappropriate to have a wife beater in a leadership position, and successfully removed the deputy prefect from office. The heartening moral of the story is the 
rapidity with which the community moved from regarding violence against women as an everyday fact of life to judging it unacceptable.

\section{SINOPSIS}

\section{Adelantos en la erradicación de la violencia contra la mujer}

En las dos últimas décadas se ha reconocido en varios foros internacionales que la violencia contra la mujer constituye una violación de los derechos humanos merecedora de mayor atención y de medidas más enérgicas. Motivados por iniciativas internacionales en torno al problema -entre ellas las expresadas en las sexta y séptima conferencias de Esposas de Jefes de Estado y de Gobierno de las Américas (1996 y 1997) — muchos países de la Región están tomando medidas para prevenir la violencia cuyo origen radica en el sexo del individuo y para ayudar a sus víctimas. Entre estas iniciativas figuran actividades de alcance nacional, como el fortalecimiento de las pautas y políticas legales en torno a la violencia contra la mujer, y también actividades de carácter comunitario, tales como la creación de redes de acción en el seno de la comunidad. En este informe se examinan brevemente algunas de las medidas que los países han adoptado a fin de eliminar las actitudes y comportamientos que obstaculizan la erradicación de la violencia contra la mujer.

\section{Primera Conferencia Iberoamericana de Tabaco o Salud}

Fechas: 23 a 27 de febrero de 1999

Lugar: Las Palmas de Gran Canaria, España

Tema: Hacia un siglo XXI libre de tabaco

En esta conferencia se tratará de los avances más recientes en métodos para evitar que los niños se inicien en el hábito de fumar y estrategias para abandonar el hábito. Otros grandes temas incluyen políticas sobre el tabaco en relación con la economía, producción, litigación, publicidad, lobbying y legislación, y la mujer y el tabaco. Se invita a los investigadores a proponer ponencias y otras contribuciones científicas sobre estos y otros temas afines, las cuales deben recibirse a más tardar el 15 de octubre de 1998.

Información:

Isabel Marcelo, Comité Organizador

Fundación Canaria de Investigación y Salud

Calle Franchy Roca 1

35007 Las Palmas de Gran Canaria

Islas Canarias, España

Tel.: +34 244986 28; Fax: +3428261728

Correo electrónico: jrcalvo@step.es

También se pueden obtener más datos, los formularios de inscripción, e información para presentar contribuciones científicas en la página web: www.rcanaria.es/tobacco99/ 